\title{
PERSEPSI KARYAWAN POLITEKNIK NEGERI JAKARTA TENTANG INCENTIVE TRAVEL TERHADAP MOTIVASI KERJA KARYAWAN
}

\author{
Dra. DIANA D C HUTAGALUNG dan Dra. MAWARTA ONIDA S, M.Si. \\ Jurusan Administrasi Niaga Politeknik Negeri Jakarta \\ Kampus UI Depok 16425
}

\begin{abstract}
After conducting this research towards "The perception of the employees of State Polytechnic of Jakarta on Incentive Travel towards motivation", it is found that there is a little perception about incentive travel happening in our campus.

It is a lack of understanding about incentive travel, eventhough they all practically do the work of incentive travel in the form of going together sometimes with their colleagues in their department. Basically, once in a year they are willing to go to spend their time together in a certain destination whether in Puncak, Bandung or even in Bali. They thought their going was a gift from their structural.

We also find that the real incentive travel has not been applied yet, because the policy or rule about incentive travel has not been made. Eventhough most of respondents said the winners are all the best employee, and the winners is given an appreciation in the form of certificate and amount of money. Yet the contest of this event has existed.

The end of writing this research, we give some suggestions to help State Polytechnic of Jakarta to be able to make the incentive travel for best employee.
\end{abstract}

Keywords: incentive travel, perception, motivation

\section{PENDAHULUAN}

Mendengar kata incentive bagi kebanyakan orang, sudah tidak asing lagi, tetapi untuk kata incentive travel bagi sebagian orang, masih banyak memberikan pemahaman yang sedikit lain. Mungkin kita sering mendengar teman-teman yang bekerja di perusahaan asuransi, MLM atau sejenisnya, dimana mereka mempunyai banyak kesempatan dalam periode tertentu untuk mendapatkan atau memenangkan incentive travel program dari perusahaan dimana mereka bekerja.

Artinya adalah dengan mendapatkan atau memenangkan program incentive travel tersebut, mereka berhak menikmati perjalanan wisata (insentive travel) yang diberikan oleh perusahaannya. Insentif itu sendiri merupakan salah satu bentuk kompensasi yang diberikan perusahaan atas prestasi yang dimiliki seorang karyawan (merit salary system), dan biasanya perusahaan akan memberikan penghargaan dalam bentuk tunai atau uang(Griffin,2006).

Dalam perkembangannya, banyak perubahan, salah satu alasan bentuk kompensasi ini berubah ke incentive travel adalah pertama, secara psikologis, karyawan dituntut bekerja dan dipacu untuk mencapai target-target tertentu, sehingga mereka sering bekerja dalam keadaan underpressure dan mengakibatkan tingkat stress meningkat. Untuk mengatasi hal itu, para pimpinan perusahaan berpendapat bahwa salah satu cara untuk menyeimbangkan kesehatan moral karyawan adalah dengan memberikan 
program insentif travel yang sedang popular saat ini (Schuter,2007).. Selain itu incentive travel diberikan atas dasar penghargaan tertinggi yang dihadiahkan agar motivasi kerja karyawan tetap terjaga dan lebih meningkat.

Kedua, pihak industri travel dengan aktifnya mengusulkan program -program yang sangat kreatif dan dikemas dengan baik sehingga pihak perusahaan dalam hal ini pihak pemakai (client) akan tertarik dengan program yang ditawarkan. Tujuannya sangat serdehana menggairahkan dunia pariwisata yang nota bene memberikan efek multiplier yang besar ke berbagai pihak yang terkait. Selain itu mendidik masyarakat untuk mencintai dunia travel agar menambah khasanah pengetahuan, belajar menerima perbedaan dari masing-masing daerah maupun berbagai tempat belahan dunia, beserta memberi rasa percaya diri kepada diri sendiri sehingga keberadaan kita patut diperhitungkan di dunia internasional.

Jadi sangatlah jelas, bagi perusahaan non pemerintah masalah insentif travel bukanlah hal yang baru, tetapi bagi instansi pemerintahan hal ini tidak pernah dinyatakan secara tersurat, apakah benar-benar insentif travel bisa diusulkan atau belum bisa diajukan sebagai suatu bentuk program kompensasi dalam meningkatkan motivasi kerja karyawan. Hal inilah yang membuat pemahaman mengenai incentive travel di kalangan karyawan PNJ beragam. Memang tugas manajemenlah yang menentukan pos penghargaan kepada karyawan dengan tujuan meningkatkan motivasi kerja karyawan untuk dapat diberikan sesuai dengan tipe insentif yang ada atau mengadakan suatu reformasi bentuk penghargaan.

Beberapa tahun belakangan ini dalam acara-acara formalitas di lingkungan PNJ seperti Dies Natalis, Lustrum atau Hari Wisuda/Graduation Day ada acara penganugerahan penghargaan kepada karyawan baik itu administrasi maupun staf pengajar (dosen dan instruktur) berdasarkan masa bekerja selama 10 tahun, 20 tahun atau lebih di lingkungan PNJ atau sebagai PNS. Ada juga yang berdasarkan prestasi kerja karyawan ataupun dosen teladan atau berprestasi. Penghargaan tersebut biasanya berupa selembar piagam penghargaan dan sejumlah uang. Hanya di beberapa tahun belakangan ini penghargaan kepada dosen berprestasi atau teladan nyaris tidak pernah terdengar lagi.

Sering kita dengar apabila ada diantara kita yang mendapatkan tugas kunjungan ke pelbagai daerah atau tempat, maka kepergian itu diasumsikan sebagai "incentive travel". Atau apabila di masing-masing jurusan mengadakan acara workshop atau lokakarya di suatu tempat (destinasi tertentu), maka mereka mengasumsikannya juga sebagai "insentif travel".

Padahal jelas jelas hal tersebut berbeda. Untuk itulah maka peneliti merasa perlu mengangkat masalah persepsi atau pandangan kita khususnya, seluruh karyawan PNJ baik dari pihak pimpinan, staf pengajar baik dosen dan instruktur, maupun administrasi, dengan tujuan untuk meluruskan pengertian incentive travel terhadap motivasi kerja karyawan.

\section{Perumusan Masalah}

1. Bagaimana pemahaman karyawan Politeknik Negeri Jakarta tentang incentive travel terhadap motivasi kerja karyawan?

2. Apakah incentive travel dapat digunakan atau diterapkan di Politeknik Negeri Jakarta dalam meningkatkan motivasi kerja karyawan?

3. Apakah terdapat perbedaan persepsi mengenai incentive travel di kalangan karyawan baik dari unsur pimpinan, staf pengajar maupun administrasi ? 


\section{TINJAUAN PUSTAKA}

\section{Persepsi}

Menurut Cushway (2003) persepsi seseorang dalam menangkap informasi dan peristiwa-peristiwa dipengaruhi oleh tiga faktor, yaitu:

1. orang yang membentuk persepsi,

2. stimulus yang berupa obyek maupun peristiwa tertentu, dan

3. stimulasi dimana pembentukan persepsi itu terjadi baik tempat, waktu maupun suasana.

Sedangkan Schuter (2007) mengemukakan bahwa komponen-komponen yang mempengaruhi persepsi ada tiga faktor, yaitu:

1. Pelaku persepsi. Seorang individu memandang suatu obyek dan mencoba menafsirkan apa yang dilihatnya, penafsiran itu sangat dipengaruhi oleh karakteristik pribadi, dari pelaku persepsi individu itu, seperti sikap, motif, kepentingan, minat, pengalaman dan harapan.

2. Sasaran/objek. Karakteristik dari target yang akan diamati dapat mempengaruhi apa yang dipersepsikan, sasaran itu mungkin berupa orang, benda atau peristiwa.

3. Situasi. Unsur lingkungan sekitarnya bisa mempengaruhi persepsi kita. Jadi persepsi harus dilihat secara konstektual, artinya dalam situasi mana persepsi itu timbul perlu mendapat perhatian.

\section{Teori Persepsi tentang Motivasi}

Kebanyakan kita mengamati karyawan yang menunjukkan motivasi dalam pekerjaan mereka. Pada saat yang sama, kita melihat karyawan kekurangan motivasi . Melihat fenomena tersebut kita akan bertanya "Faktor apa yang memberi andil dan berkaitan dengan efek negative terhadap motivasi seseorang? Apa yang menimbulkan kegairahan seseorang dalam bekerja, dan apa yang menurunkan antusiame seseorang dalam bekerja dan factor apa yang cenderung meningkatkan motivasi kerja? Mengapa sebagian orang merasakan motivasi dan sebagian lainnya tidak? Menurut Pace (2000), pengalaman hidup dalam organisasi menunjukkan bahwa motivasi kerja didasarkan atas 4 (empat) asumsi utama, yaitu :

1. Harapan, seberapa jauh harapan karyawan dipenuhi oleh organisasi.

2. Peluang, apa yang dipikirkan karyawan mengenai peluang mereka dalam organisasi.

3. Pemenuhan, bagaimana pendapat karyawan mengenai seberapa banyak pemenuhan yang diperoleh dari pekerjaan dalam organisasi.

4. Kinerja, bagaimana persepsi karyawan mengenai kinerja mereka dalam organisasi.

\section{Incentive Travel}

Pengertian Incentive Travel adalah bentuk penghargaan tertinggi kepada the winner(s) yaitu orang-orang pekerja yang berprestasi/berkinerja tinggi yang berupa program perjalanan wisata baik individu maupun perkelompok yang sifat programnya once in a life time and unforgettable moment artinya program insentive travel tersebut merupakan suatu wisata travel yang diberikan mempunyai suatu kontrak psikologis antara sipemberi kerja dan sipekerja dan hal itu berupa suatu wisata yang dikemas dengan nilai lebih (spektakuler) berdasarkan kebutuhan, harapan dan tujuan sipemberi kerja. Biasanya alasan sipemberi kerja menggunakan program insentive travel ini dikarenakan nilai emotional dan psikologis berupa pengalaman wisata inilah yang tidak akan hilang di memori si pekerja, sehingga nilai kepuasan akan insentif yang 
diterima dalam bentuk perjalanan wisata dapat memberikan signifikansi yang lebih kepada sipemberi kerja.

Jenis insentive travel yang dapat diberikan dapat bermacam-macam, ada yang dikemas secara tailormade atau pesanan, ada juga dalam bentuk voucher disesuaikan dengan budget/anggaran sipemberikerja. Contohnya ada 2(dua) voucher pergi umroh yang dapat diprogramkan pada suatu perusahaan dimana para pekerja akan termotivasi untuk mendapatkannya dengan bekerja sebaik mungkin untuk meraih kesempatan itu. Di sini kita dapat melihat bahwa perusahaan dalam mendisain dan mengimplementasikan program insentive travel haruslah sesuai dengan tujuan perusahaan sehingga para peserta (penerima) insentive travel akan mengerti harapanharapan dari perusahaannya, sehingga tujuan program tercapai dengan sukses. Tentu saja itu tujuan program insentive travel ini juga melihat dan mempertimbangkan kebutuhan dari para pekerjanya (calon penerima penghargaan).

Khususnya untuk mendisain program insentive travel bagi karyawan adalah bertujuan untuk meningkatkan performance kerja/ kinerja, menaikkan moral kerja dan loyalty (kesetiaan /kepatuhan), memperbaiki tingkat kesejahteraan, memperbaiki atmosphere kerja dengan menguatkan kerja tim dan motivasi

\section{TUJUAN DAN MANFAAT PENELITIAN}

Adapun tujuan penelitan sebagai berikut :

1. Untuk mengetahui pandangan atau persepsi karyawan PNJ mengenai incentive travel.

2. Untuk mengetahui incentive travel dapat digunakan sebagai salah satu alternatif dalam pemberian penghargaan kepada karyawan berprestasi.

3. Untuk mengetahui perbedaan persepsi tentang incentive travel di kalangan karyawan PNJ.

4. Untuk memberi masukkan kepada institusi PNJ berupa rekomendasi jenis insentive travel yang dapat digunakan.

\section{Manfaat Penelitian}

1. Dapat dijadikan sebagai bahan masukan untuk pertimbangan dalam mengambil langkah-langkah yang strategis dalam pembuatan suatu kebijakan/ aturan pemberian penghargaan kepada pegawai berprestasi.

2. Dapat dijadikan bahan masukan untuk mengevaluasi kelebihan dan kekurangan yang ada untuk dapat diperbaiki.

\section{METODE PENELITIAN}

Populasi yang menjadi penelitian ini adalah seluruh karyawan Politeknik Negeri Jakarta, yang terdiri dari 295 dosen tetap, 12 instruktur, dan 214 staf administrasi. Jadi, sampel penelitian adalah 52 orang yang terdiri dari 10 unsur pimpinan, 21 dosen dan 21 staf administrasi.

Teknik yang dipakai dalam pengumpulan data untuk penelitian ini adalah bersifat deskriptif yang bertujuan untuk mendeskripsikan atau menjelaskan peristiwa atau kejadian yang sedang berlangsung pada saat penelitian tanpa menghiraukan sebelum dan sesudahnya (Sudjana,2000). 


\section{HASIL PENELITIAN DAN PEMBAHASAN}

a. Dari jawaban pertanyaan no 1 mengenai adakah kebijakan incentive travel di lingkungan kerja anda, peneliti memperolehnya dari sisi pemberi kerja. Dengan semua responden menjawab tidak yang berarti bahwa di Politeknik Negeri Jakarta belum/ tidak ada rujukan kebijakan yang mengatur incentive travel di lingkungan kerja ini. Sehingga pertanyaan selanjutnya tidak ada satupun yang dapat mengisi mengenai aturannya. Seperti kita ketahui bahwa kebijakan incentive travel haruslah selalu berasal dari top manajemen / pihak decision maker yang akan menentukan apakah mereka akan mengambil kebijakan tersebut atau tidak dengan mempertimbangkan banyak factor.

b. Mengenal kata incentive travel untuk pertama kalinya, sebagian besar tidak menjawab mencerminkan bahwa memang mereka belum mengenal kata tersebut atau dengan kata lain mereka belum tahu arti substansi nya. Sehingga dapat dikatakan pemahaman mereka mengenai incentive travel sangatlah kurang.

c. Hanya $28,8 \%$ yang menjawab pegawai /karyawan berprestasi baik itu dosen dan administrasi, dan selebihnya tidak menjawab. Hal ini dapat dikatakan bahwa bisa saja mereka tidak tahu atau memang belum ada aturannya. The winners di sini adalah para peserta yang berhak mendapatkan incentive travel dari program incentive travel yang diadakan di lingkungan kerjanya, otomatis aturan kerjanya sudah ada dan diatur oleh pemberi insentif/ decision maker. Dan the winner tersebut dapat dikategorikan dua jenis yaitu employee /pegawai dan non employee/ sales / distributor maupun custormer.

d. Selanjutnya adalah mengenai bentuk penghargaan untuk pemilihan karyawan berprestasi dan dosen berprestasi yang pantas diberikan untuk mereka. 28,8\% menjawab sertifikatlah yang baik dan pantas diberikan, meskipun uang dan penghargaan memegang posisi yang sama yaitu 19,2\%. Cukup menggembirakan bahwa ada yang menjawab jalan -jalan keluar kota patut diberikan sebagai imbalan kepada pemenang dari kontes karyawan berprestasi. Meskipun demikian tidak menutup kemungkinan yang menjawab minta disekolahkan sebesar 13,4 \% yang artinya bahwa pengembangan staff development masih perlu ditingkatkan lagi. Dalam hal incentive travel, memang masalah pemberian awards memegang peranan yang penting. Karena di sinilah rule / game yang dipertaruhkan dari suatu organisasi pantas dipersembahkan kepada karyawan terbaiknya. Dari pemberi insentif/ pihak decision maker semuanya menjawab dengan sertificate dan uang. Dan memang itulah yang kita lihat dalam kontes event tersebut dari tahun ketahun.

e. Kepergian atau jalan-jalan bersama teman-teman sejurusan merupakan suatu hal yang sangat dinanti-nanti. Pemilihan destinasi masih sekitar Puncak, Bandung dan yang paling jauh adalah Bali dengan 19,2 \%. Pemilihan destinasi masih inbound yang artinya masih berada di wilayah Indonesia bukan ke luar negeri. Tapi masih ada yang menjawab lupa dengan 3,8 \% dan tidak pernah dengan 5,9 $\%$. Yang menjawab tidak pernah peneliti melihat bahwa mereka adalah para administrasi yang berada di gedung Q.

f. Kapan terakhir pergi jalan-jalan ternyata $25,11 \%$ menjawab di bulan Februari 2009 dan disusul Agustus 2009, dan intinya bahwa para responden menjawab masih di tahun 2009 medapat porsi terbanyak. Meskipun demikian masih ada yang menjawab lupa dengan $3,8 \%$.

g. Kebersediaan para peserta mengikuti event tersebut, maka dijawab ya oleh 86,6\% dan yang menjawab dengan tidak $13,4 \%$. Ini berarti minat dan keantusiasan para karyawan begitu besar dan baik sekali. Dapat dikatakan bahwa teori 
Herzberg dapat terlihat dalam ukuran ini, karena bukanlah uang yang menjadi alat motivasi, melainkan factor-faktor pendorong semangat lain

h. Perasaan para peserta dalam mengikuti program incentive travel cukup berpengaruh dalam jalannya acara tersebut. Sehingga 96,15\% menjawab ya dalam mengungkapkan perasaan senangnya dalam bepergian bersama-sama teman. Dan yang menjawab tidak, benar-benar tidak ada, hanya tidak menjawab sebesar 3,85\%.

i. Salah satu ciri khas dari incentive travel adalah unforgettable moment dan once in a life time. Artinya adalah bahwa kepergian dalam acara incentive travel tersebut para pesertanya merasa bahwa kepergian tersebut mempunyai kenangan yang tidak dapat mereka lupakan dan selalu menjadi yang terindah. Once in a life time merupakan kepergian yang sekali seumur hidup, meskipun setengah dari para responden menjawab Puncak dan Bandung sebagai destinasinya. 75,04\% menjawab kepergian bersama sama teman mempunyai unsur unforgettable moment.

j. $86,53 \%$ menjawab bisa pergi jalan-jalan merupakan incentive travel dari lingkungan kerjanya, sedangkan 9,61\% menjawab tidak bisa, dan 3,84\% tidak menjawab. Pemahaman / persepsi mereka mengenai kepergian /jalan bersama teman sejurusan bisa dibilang positive karena mayoritas menginterprestasikan pergi jalan-jalan dapat dikatakan sebagai program incentive travel.

k. Penghargaan yang sepatutnya dapat diberikan kepada karyawan berprestasi dapat berupa sertifikat dan uang $(32,69 \%)$ dan sebanyak $28,84 \%$ mengatakan incentive travel. Hal ini dapat dikatakan bahwa pemberian penghargaan yang masih terbaik dan terjangkau berupa sertifikat dan uang, Meskipun posisi kedua memenangkan incentive travel, tetapi masih ada yang berpengharapan menerima gaji/kenaikan gaji, training/pendidikan (short course), bahkan 3,84\% berpengharapan mendapatkan rumah dan isinya. Sedangkan 7,69 \% masingmasing hanya mengharapkan penghargaan dan pengakuan saja, dan 1,92\% pasrah mau menerima apa saja.

1. Ternyata gaji yang baik masih merupakan factor yang sangat mempengaruhi pegawai bekerja dengan baik. Ini membuktikan bahwa mendapatkan gaji yang baik merupakan motivator yang kuat bagi mereka yang ingin mendapatkan penghargaan. Dan bantuan simpatik atas masalah pribadi merupakan rangking ke 10 atau terakhir yang artinya masih sedikit atau kecil sekali dari para responden untuk berbagi/sharing apabila mengalami kesulitan masalah, dan hal ini lebih baik di pecahkan sendiri.

m. 86,53 \% menjawab ya bahwa para responden termotivasi bekerja lebih keras untuk mendapatkan suatu penghargaan. Secara organisasi hal ini sangatlah positive. Dalam teori persepsi tentang motivasi dimana peluang merupakan salah satu unsur yang paling kuat dari empat unsur yang mempengaruhi vitalitas kerja. Dan peluang itu menggambarkan suatu situasi atau kondisi yang menyenangkan untuk mencapai suatu tujuan. Peluang juga mempengaruhi aspirasi seorang pegawai atau prestasi yang diinginkan. Dan peluang juga mempengaruhi sejauh mana komitmen pegawai terhadap organisasi. Biasanya mereka yang mengalami pertumbuhan pribadi dan penghargaan cenderung menaruh perasaan positif kepada organisasi. Mereka menjadi termotivasi untuk melakukan lebih banyak lagi, mencurahkan waktu extra untuk bekerja, mencari cara lain untuk memberikan konstribusi, dan mencoba cara inovatif untuk meningkatkan produktivitas. Sedangkan mereka yang menerima informasi negative berangsurangsur mundur dari atau meninggalkan organisasi. 
n. $100 \%$ menjawab senang bekerja. Dan terlihat bahwa ini adalah suatu kenyataan yang patut disyukuri.

\section{Kesimpulan}

1. Pemahaman karyawan Politeknik Negeri Jakarta tentang Incentive Travel terhadap motivasi kerja masih sedikit atau kurang, hal ini dapat dilihat pemahaman yang kurang mengenai pengenalan kata incentive travel dan siapa para the winnersnya beserta decision makers. Meskipun demikian secara substansi ada kesan bahwa kepergian /jalan jalan bersama teman di jurusan minimal setahun sekali bisa di katakan merupakan program insentif travel.

2. Program Incentive travel di Politeknik Negeri Jakarta belum dapat diterapkan karena belum ada rujukan/kebijakan yang mengaturnya.

3. Perbedaan persepsi mengenai incentive travel diantara unsur pimpinan, staf pengajar dan administrasi terjadi sedikit sekali, karena pemahaman mereka mengenai incentive travel kurang dan hanya dari jurusan Administrasi Niaga yang bisa memberikan jawaban cukup memuaskan.

\section{Saran}

Alangkah baiknya apabila hasil penelitian ini bisa dipakai sebagai bahan rujukan dalam membuat suatu kebijakan ditingkat pusat, dalam hal ini adalah segala sesuatu yang mengatur kinerja karyawan, motivasi karyawan yang dapat berupa program incentive travel baik wisata umroh dan ke tanah suci.

\section{DAFTAR PUSTAKA}

Cushway,Barry dan Derek Lodge. 2003. Organizational Behavior and Design Perilaku dan Desain Organisasi, Jakarta : Erlangga

Griffin, W Ricky dan Ronald J.Ebert.2006. Bisnis, Jakarta :LPPM

Schuter, Randall S dan Susan E Jackson. 2006. Manajemen Sumber Daya Manusia Menghadap Abad ke 21 Jilid 2, Jakarta : LPPM

Sudjana, Panuti dan Dendy Sugiono.2000.Penelitian Untuk Ilmu Sosial, Jakarta Sugiono.2008. Statistika Untuk Penulisan, Bandung : Alfabeta

Pace, R Wayne dan Don F Faules.2000. Komunikasi Organisasi-Strategi Meningkatkan Kinerja Perusahaan, Bandung: Remaja Rosdakarya

Examples of Employee Incentive Programs ( http://www.eliteincentivetravel.com) diakses 26 February 2008

Making Incentive Travel Work ( http://maritz ) diakses 30 Agustus 2008

Motivating through Incentives ( http://dailyplan-it.net ) diakses 26 Februari 2008

World Incentives.com Program Incentive Travel diakses Maret 2009 
